\title{
Some Unorthodox Thoughts About Rising SeA LeVels, BeACH ERosion, ANd Property Rights
}

\author{
Joseph L. Sax*
}

When legal problems arise involving migrating seashores, they are routinely posed as regulatory takings issues. The usual setting is a restriction on seawall construction, ' a setback regulation, a claimed public easement across the beach, or (as in the most recent case to come before the U.S. Supreme Court ${ }^{2}$ ) an asserted loss of littoral rights emanating from a beach nourishment program.

The conventional way to characterize these cases is that a landowner wants to exercise his property rights and a government wants to restrict those uses to achieve a public purpose, the question being who ought to pay for the (proprietary) burden thus imposed, and the (public) benefit thus achieved. I propose here an alternative way of looking at these controversies.

In short, I suggest that most such cases should be seen as disputes between two neighboring proprietors, the state and a littoral owner, each of which has legitimate proprietary interests at stake. At what is literally a line drawn in the sand, the line of mean high tide (MHTL) is a property boundary. ${ }^{3}$ Landward of that line are (usually) private littoral landowners. ${ }^{4}$

* James H. House and Hiram H. Hurd Endowment Professor of Environmental Regulation, Emeritus, Univ. of California, Berkeley.

1. I will use the term "seawall" generically to describe a variety of wall-like structures, including revetments and bulkheads. Similar purposes are sometimes achieved with jetties or groins, structures that extend out into the water and may function to shift the deposition of sand toward or away from nearby beaches.

2. See Walton County v. Stop the Beach Renourishment, Inc., 998 So. $2 d 1102$ (Fla. 2008), cert. granted, 77 U.S.L.W. 3673 (U.S. June 15, 2009) (No. 08-1151) (U.S. argued Dec. 2, 2009). At the Supreme Court level, the party names are now Stop the Beach Renourishment, Inc. v. Florida Department of Environmental Protection. Id.

3. Various terms are used to describe the MHTL. On non-tidal, navigable waters it is usually called the line of ordinary, or mean, high water, and those terms are also sometimes used for tidal waters. The technical issues and ambiguities involved in defining and measuring these locations are not in issue here. See generally BRUCE C. FLUSHMAN, WATER BOUNDARIES: DEMYSTIFYING LAND BOUNDARIES ADJACENT TO TIDAL OR NAVIGABLE WATERS, 68-69 (2002) (describing essential legal terminology and principles involved in defining property boundaries for navigable and tidal waters).

4. On the sea, owners of land adjacent to the water are called "littoral," while on rivers they are called "riparian"; legally, the same rules apply. The terms can be used interchangeably. 
Usually, seaward of that line is the state, a public landowner. Each of those landowners has certain proprietary rights. I emphasize that I am describing only state proprietorship that is indisputable under any view of background principles of property law. For purposes of this article, I put aside any dispute about whether some state proprietary claims, like the customary uses of beaches in Oregon and Texas, should-as Justice Scalia suggested some sixteen years ago-be rejected as "pretextual."s

Under ordinary circumstances, there is nothing particularly obscure or mysterious about these rights. For example, the littoral owner has a right to occupy and make economically productive use of his land. The state is entitled to have the public use the foreshore (the wet beach between high and low tide) for passage and recreation, ${ }^{6}$ and to employ coastal wetlands seaward of the MHTL as habitat. Assuming a rather stable situation at the water's edge, with the boundary moving modestly back and forth over time, these two uses can coexist with little or no conflict.

But where the sea is substantially and continuously rising, or where violent storms periodically wipe away massive areas of sand beach, littoral owners are understandably anxious to protect their upland. Generally, they want to build a protective device (I will use the term "seawall" generically to describe all such devices) to hold back the rising sea or storm wave action. In the case of rising sea levels, absent a seawall, the ocean migrates landward and the foreshore (with its public uses) migrates with it. If a seawall is constructed, when the water rises to the elevation of the seawall, the foreshore and coastal wetlands disappear-the ocean simply meets the wall. ${ }^{7}$ Moreover, the presence of a seawall intensifies the force of the wave

5. Stevens v. City of Cannon Beach, 854 P.2d 449 (Ore. 1993) (Scalia, J., dissenting).

6. In some states, public use rights extend farther upland, e.g., to the vegetation line, under a number of different legal theories and historical uses. See, e.g., Texas Open Beaches Act, TEX. NAT. RES. CODE ANN. § 61.011(a) (2009); Application of Ashford, 440 P.2d 76, 77 (Haw. 1968); Diamond v. State, 145 P.3d 704, 712 (Haw. 2006); Glass v. Goeckel, 703 N.W.2d 58, 72-73 (Mich. 2005).

In other states, especially in New England, littoral owners have been granted title down to the low tide line, subject to some public use rights, and some states, like Massachusetts and Maine, have limited public uses on these privately owned foreshore areas for traditional fishing, fowling, and navigation, but not general passage and recreation. See, e.g., Bell v. Town of Wells, 557 A.2d 168, 169 (Me. 1989); In re Opinion of the Justices, 313 N.E.2d 561, 567 (Mass. 1974). Others take a broader view of the public trust limitations that remain on such grants. See, e.g., Champlin's Realty Assocs. v. Tillson, 823 A.2d 1162, 1167 (R.I. 2003).

7. A recent Ninth Circuit decision held that on an eroding shoreline the property line migrated landward, despite the presence of a seawall, to where the MHTL would have intersected the land had there not been a seawall preventing its migration. Because the case involved an Indian Reservation and federal trust ownership of the land seaward of the MHTL, in contrast to the usual state ownership under the equal footing doctrine, the court fashioned federal common law, and acknowledged that its decision might be of very limited application. The decision, if applied generally, might make many homes now behind seawalls trespassers on state property. United States (Lummi Nation) v. Milner, 583 F.3d 1174, 
action hitting against it, accelerating the loss of the sand beach and the foreshore.

The reason for reciting these well-known facts is to suggest something that is not so well known, or at least not well recognized. It makes an important difference in all of these settings that the state is not simply a regulator, but is also a proprietor. ${ }^{8}$ As a proprietor, the state has pre-existing entitlements of its own that stand on par with those of other proprietors, including its neighbors. In such settings, the state is not simply diminishing some pre-existing entitlement that regulated parties (other proprietors) enjoyed. It is also safeguarding its own pre-existing rights.

The law is well settled that in its proprietary capacity the state is entitled to assert its ownership rights in the same way, and with the same vigor, as any other owner. ${ }^{9}$ Of course, the state is also making the rules, and where it chooses to rest on its proprietary interests, ${ }^{10}$ it should stand before

1189 (9th Cir. 2009); see also Wilson v. Omaha Indian Tribe, 442 U.S. 653, 669-71 (1979) (outlining the application of federal common law to migratory shorelines involving treaty reservations). On the right to defend one's property generally, see infra note 14.

8. State ownership of tidelands is not simply a "legal fiction" or a metaphor. Cf. Hughes v. Oklahoma, 441 U.S. 322, 335-36 (1979) (stating there are legitimate state concerns, not inconsistent with the commerce clause, underlying the legal fiction of state ownership of wild animals).

9. See Wilkie v. Robbins, 551 U.S. 537, 557 (2007) ("Just as a private landowner . . . may press charges of trespass every time a cow wanders across the property line or call the authorities to report every land-use violation, the Govemment too may stand firm on its rights and use its power to protect public property interests."); see also Int'l Soc'y for Krishna Consciousness, Inc. v. Lee, 505 U.S. 672,678 (1992) ("Where the government is acting as a proprietor" different standards apply than when it is acting simply in its regulatory capacity); Washoe County v. United States, 319 F.3d 1320, 1327-28 (Fed. Cir. 2003) ("[T]he government was acting as a landowner whose neighbor sought permission to lay a pipeline across its property.... [It] had no obligation as a neighbor to assist [its neighbors] ....").

As Justice Brandeis put it many years ago, "The character of the [s]tate's ownership in the land and in the waters is the full proprietary right." Port of Seattle v. Or. \& Wash. R.R., 255 U.S. 56, 63 (1921). The exact nature of the state's proprietorship of tidelands is sometimes disputed, see, e.g., Fabrikant v. Currituck County, 621 S.E.2d 19, 27 (N.C.Ct. App. 2005) (discussing whether "claim of title" to tidelands by state is shown by public trespass on land), but it cannot be doubted that the state has ownership rights sufficient to defend and protect the uses for which, as sovereign it holds the lands beneath navigable waters. The position of most states is that "not only does the State hold title to this land in jus privatum, it holds it in jus publicum, in trust for the benefit of all the citizens of the ... State." McQueen v. S.C. Coastal Council, 580 S.E.2d 116, 119 (S.C. 2003) (emphasis in original) (citing State v. Pac. Guano Co., 22 S.C. 50, 84 (1884)).

And as a state court put it in one seashore case, "If the judge finds that the revetment was to be built on the Commonwealth's property, we do not hesitate to note that such a situation could never describe a compensable taking." Wilson v. Massachusetts, 583 N.E.2d 894, 900 n.15 (Mass. 1992), aff'd, 597 N.E.2d 43, 43 (Mass. 1992).

10. The state has a choice. It can forego its status as an owner, and rely on its regulatory authority, in which case, if the regulation is challenged as a taking, the constitutional regulatory takings analysis would apply. My assumption here is that in some instances involving sea level change, the state might well be better off, or at least as well off, resting on its proprietary rights, as I seek to illustrate in discussing Stop the Beach Renourishment, Inc., infra. 
a court like any other owner. When the state makes such claims, its position as governor and rule-maker should carry no weight. As a proprietor, it should be neither worse off nor better off than any other proprietor."

As an owner, the state's legal position might be more favorable than its position as a regulator. Illustratively, if a state as the owner of tidelands deprives the private upland littoral owner of access to the water, from the conventional regulatory takings perspective that would a priori seem to present the expropriation of a common law littoral right of access. But analyzed as a proprietary case, it may look entirely different. In a controversy where the state granted tideland it owned to a third party, who then filled those lands thereby cutting off the littoral owner's water access, the U.S. Supreme Court held that so long as the state's action was compatible with the purposes for which it owned the tideland, i.e., "in aid of commerce," the state could dispose of its tidelands free from any access claim of the upland proprietor. ${ }^{12}$ It was exercising a legitimate proprietary right.

Of course, the outcome in that case was rather extreme. In general, as I suggest below, the courts should seek an equitable balance between the legitimate claims of both the upland owner and the state, as some regulatory schemes do now. Thus, for example, in exchange for permission to construct a seawall, a littoral owner might be required to permit public access across its upland, or to provide mitigation for lost habitat formerly within the publicly owned foreshore, or both.

In addition to the desire for balanced resolution of today's seashore cases, as contrasted to the either/or outcomes provided in regulatory takings

11. There are various situations where government acts both as a proprietor and as a sovereign. The government uses its regulatory authority to implement its proprietary rights, as on national forests, where private parties claim easements across public land. See United States v. Jenks, 22 F.3d 1513,1518 (10th Cir. 1994) (describing the permit process used to effectuate an easement across its land and limit use to scope of the easement). Another situation is where municipally owned airports are authorized to implement noise regulations. Obviously, there is a potential for conflict in such situations, but courts have been able to deal with the problem, e.g., assuring that regulation given for that limited purpose is used solely for the protection of proprietary rights, such as preventing noise that amounts to a nuisance. See British Airways Bd. v. Port Auth. of N.Y., 558 F.2d 75, 83 (2d Cir. 1977) (a state or local agency, as proprietor of an airport, may still implement regulations to control noise); see also State ex rel. King v. H.F. Wilcox Oil \& Gas Co., 19 P.2d 572, 575 (Okla. 1933) (stating that a state as sovereign regulates production, and is also a competing landowner of oil land). Courts can easily separate two different claims by the state, one as an owner, and the other as a regulator, and apply the proper standards to each.

12. United States v. Mission Rock Co., 189 U.S. 391, 405, 407 (1903) (citing Shively v. Bowlby, 152 U.S. 1 (1894)). See infra notes 31-32. State laws and regulations expressly recognize a state's interest in tidelands as "proprietary" and not merely regulatory. E.g., 310 MASS. CODE REGS. 9.02 (2009) (defining "trust lands" as waterways in which the fee simple, any easement, or other proprietary interest is held by the Commonwealth in trust for the benefit of the public."). 
cases, other reasons may make regulatory takings analysis inapt for these cases.

The categorical takings rules usually do not fit these cases. As the sea rises, if the accretion/erosion rule is applied, the sea and the state's migratory ownership will cover the upland. That looks like a physical invasion of the upland owner's property, but it hardly seems appropriate that application of the traditional common law erosion rule would ipso facto constitute a taking of the upland owner's property. ${ }^{13}$ Conversely, application of a traditional defense-of-property rule on behalf of the upland owner would (as described above) allow the state's proprietary interest to be destroyed. ${ }^{14}$

Traditional common law rules do not fit contemporary circumstances. For example, in previous eras, the foreshore was not important for public recreational use or as habitat, and the right (even the obligation under the English common law, known as "inning") of upland owners to defend against rising waters was not in conflict with public ownership of the sea up to the (migrating) line of mean high tide. Nor was the migratory boundary that moved with accretion and erosion unidirectional, as it is with modern sea level rise, so it was not so threatening to upland owners.

The rate and magnitude of the rising sea levels are physically quite different from the historical experience out of which the common law rules grew. The rising sea level is neither gradual like traditional accretion, erosion, or reliction; nor is it sudden and violent like traditional avulsion. We are facing a historically distinct situation that is not a good factual fit with the "background" rules.

13. The alternative view is that nature will take its course and landowners will have to retreat when the sea moves inland. See, e.g., Arrington v. Mattox, 767 S.W.2d 957, 958 (Ct. App. Tex. 1989) ("This public right of use or easement migrates and moves landward or seaward with the natural movements of . . . the line of mean low tide.").

14. E.g., Rex v. Comm'rs, (1828) 108 Eng.Rep. 1075, 1077 (K.B.) (“[E]very land-owner exposed to the inroads of the sea has a right to protect himself, and is justified in making and erecting such works as are necessary for that purpose.... [ []f they act bonâ fide, doing no more than they honestly think necessary for the protection of the level, their acts are justifiable, and those who sustain damage therefrom must protect themselves."); Katenkamp v. Union Realty Co., 59 P.2d 473, 476-77 (Cal. 1936). Contra Grundy v. Thurston County, 117 P.3d 1089, 1093-94 (Wash. 2005) (regarding a nuisance suit for seawater storm damage from a neighbor's seawall). Traditional conceptions of the right to defend one's property against natural hazards have undergone considerable rethinking in light of the modern commitment to protect wildlife, and modem courts struggle to accommodate the public and private values. E.g., Baldwin v. Fish \& Game Comm'n, 436 U.S. 371, 385-86 (1978); Christy v. Hodel, 857 F.2d 1324, 1334-35 (9th Cir. 1988); State v. Thompson, 33 P.3d 213, 216 (Idaho Ct. App. 2001); Commonwealth v. Hagan, Nos. 1999-205 \& 1999-206, 2000 WL 1137827 (Ct. of C.P. of Elk County, Pa. Jan. 3, 2000); see also Lauri Alsup, The Right to Protect Property, 21 ENVTL. L. 209, 216-17 (1991). 
In thinking about how to analyze these cases, the enemy waters problem provides a helpful analogy. Those cases also involve two neighboring owners at odds over an invasive natural hazard. ${ }^{15}$ The evolution of doctrine in those cases is instructive. Traditionally, the law acknowledged only one owner's rights. In some jurisdictions, the so-called "common enemy doctrine" applied. ${ }^{16}$ It permitted an owner to defend his property, and thus to do whatever he wished on his own land to get rid of the unwanted water. That approach took no account of the owner who was not physically positioned to defend himself. ${ }^{17}$ The other traditional approach, the so-called "civil law rule," held that the natural situation must be left alone, that one must simply abide whatever natural flows brought. ${ }^{18}$

Today, both of those extreme solutions have given way to a balancing approach that seeks an accommodation sensitive to the fact that both owners have a legitimate interest and are innocent victims of a phenomenon beyond their control. ${ }^{19}$ In effect, a balancing approach has replaced an either/or approach, and rigidity of result yielded to a consequentialist accommodation of competing entitlements, which recognizes the legitimacy of each party's proprietary claim.

A California opinion written some forty years ago put the issue nicely, employing a distinction between tort and property mentalities to illustrate the difference between flexibility and rigidity:

[W]e are urged to consider the reasonable use rule as an attempt to cope with the problem [of enemy waters] through the use of tort rather than property concepts. . . . Such words as "right", "servitude", and "easement" connote a state that is fixed and definite, and they cannot be applied in those terms to describe flexible legal relations dependent upon varying circumstances. ... [W] [Wile tort

15. See generally RESTATEMENT (SECOND) OF TORTS $\S 833$ (suggesting it may be a nuisance to invade one's interest in landed property by interfering with the flow of surface water).

16. In parallel to the problem presented by rising sea levels, the common enemy doctrine held that a threatened landowner need not concern himself with the effect of his action, but could "deal with it in such a manner as best suits his own convenience; . . . includ[ing] walling the water . . . out ...." Pflum v. Wayne County Bd. of Comm'rs, 892 N.E.2d 233, 237 (Ind. Ct. App. 2008).

17. See id.

18. Page Motor Co., Inc. v. Baker, 438 A.2d 739, 742 (Conn. 1980) ("Some jurisdictions have adopted the civil law rule which holds that 'the right of drainage of surface-waters, as between owners of adjacent lands, of different elevations, is governed by the law of nature."') (quoting Rutkoski v. Zalaski, 96 A. 365 (Conn. 1916)).

19. E.g., id. at 741 ("[T] he landowner, in dealing with surface water, is entitled to take only such steps as are reasonable, in light of all the circumstances of relative advantage to the actor and disadvantage to the adjoining landowners, as well as social utility. Ordinarily, the determination of such reasonableness is regarded as involving factual issues to be determined by the trier."). 
terminology is not necessarily a panacea, a court is more likely to produce an acceptable result if it analyzes "prerequisites of liability" rather than merely the "rights of the parties." 20

Whatever the proper label may be, the idea is that the presence of two legitimate preexisting rights calls for reasonable accommodation, rather than an either/or resolution.

A hypothetical example drawn from a recently filed case illustrates the poor fit of traditional rules to contemporary problems. There is a spit of land with the ocean on one side and an inlet on the other with valuable undeveloped real estate along its spine. ${ }^{21}$ With the water rising and eroding the shore, an application to build a seawall is denied. ${ }^{22}$ The state has a setback law that is measured by an estimate of the rate of erosion (forty years back from the shore, at the present rate of erosion). ${ }^{23}$ While such a law makes good sense in a stable or very slowly changing situation, in the circumstance of a rapidly disappearing beach, such a setback rule would soon put all the privately owned land within the setback zone, making it worthless to the owner. ${ }^{24}$

Setback laws are usually a good management tool, keeping development and the demand for seawalls back enough to assure maintenance of a public foreshore. But where protection of one property interest threatens to swallow the other, such measures do not do the job. Either the setback law takes the upland tract, or it does not. If the property is very valuable for development, it would seem that whatever public uses would be lost to the public as the result of a seawall might be dealt with by requiring a mitigation payment as the price for permitting a seawall. There may be a variety of other accommodations. The important point is that dramatically rising sea levels and intensified storm-caused erosion are going to present many variations on this sort of problem, and traditional rules are poorly calculated to deal with them.

The Florida case now before the U.S. Supreme Court, although arising out of erosive storm damage rather than out of sea level rise, also illustrates

20. Keys v. Romley, 412 P.2d 529, 535-36 (Cal. 1966).

21. Kiawah Dev. Partners v. S.C. Dep't of Health \& Envtl. Control, No. 2009-CP-10-2847 (Ct. of C.P. of Charleston County, S.C., May 5, 2009).

22. Id. See also S.C. Coastal Conservation League v. S.C. Dep't of Health \& Envtl. Control, 548 S.E.2d 887, 896 (S.C. App. 2001) (holding that the Beachfront Management Act prohibits the Department from issuing a permit to construct new or existing groins).

23. S.C. CODE ANN. \$ 48-39-280 (2009).

24. F. Patrick Hubbard, The Impact of Lucas on Coastal Development: Background Principles, the Public Trust Doctrine, and Global Warming, 16 SOUTHEASTERN ENVTL. L.J. 65, 80 (2007) (suggesting that a setback rule based on predicted erosion would lead to legal challenges). 
the unsuitability of the conventional rules and standard regulatory takings analysis to such situations. ${ }^{25}$ The actual setting in that case is a state statute that substitutes a fixed property line for the migratory MHTL. ${ }^{26}$ But effectively the claim is that the state, by building a public beach in front of the littoral tract, destroys two elements of a littoral owner's property right: physical adjacency to the water and the right to future accretions.

As the case has been presented and briefed (putting aside a judicial takings issue and other jurisdictional matters), it presents a regulatory taking claim: the landowner had certain preexisting property rights and expectations (adjacency, accretions), and the government has stripped them away to achieve some public benefit. Thus conceived, the dispute turns on questions such as whether adjacency, rather than merely access, is a littoral right under Florida law; whether adjacency would be considered a property right by state law in the context of a beach nourishment program that maintained access; and whether the claimed right to future accretions, which are only a contingent possibility, are property rights. (Because the case arose as a facial challenge to the statute, the Penn Central standards are not at issue in the case before the Court). ${ }^{27}$

My suggestion is that the case, thus conceived, misses a fundamentally important point. The state also has important property rights. The case should turn on a balance between the littoral owner's claimed property rights and the state's property rights as the owner of the land seaward of the MHTL. From my reading of the various papers in the case, that issue was not even raised, except in the amicus brief of the Coastal States Organization. ${ }^{28}$

In any event, the shape of the Florida case would be entirely different if it turned out that the beach nourishment program could be defended as an exercise of a preexisting property right that the State itself had as a proprietor. If that were so, even if some preexisting property rights of the littoral owner were impaired or destroyed, the issue in that case would be entirely different from the issues in a regulatory takings case.

What is the State's potential proprietary interest? I am not an expert on Florida law, and I do not assert that Florida courts would necessarily

25. See Walton County v. Stop the Beach Renourishment, Inc., 998 So. 2d 1102 (Fla. 2008), cert. granted, 77 U.S.L.W. 3673 (U.S. June 15, 2009) (No. 08-1151) (U.S. argued Dec. 2, 2009). At the Supreme Court level, the party names are now Stop the Beach Renourishment, Inc. v. Florida Department of Environmental Protection. Id.

26. Stop the Beach Renourishment, Inc., 998 So. 2 d at 1107.

27. Id. at $1105 \mathrm{n} .1$.

28. Cf. Brief for Coastal States Organization Supporting Respondents at 32-36, Stop the Beach Renourishment, Inc. v. Fla. Dep't of Envtl. Prot., No. 08-1151 (U.S. Oct. 5, 2009). 
recognize the following, but here is one possible way to look at the Florida case from a state-proprietary perspective.

The legal posture of the State (entirely apart from the statute in question in the case) would be that it was simply filling in its own submerged land. Such a deliberate filling process, it would assert, is not accretion under Florida law, and therefore the new land is a state-owned beach. Since the filling assertedly would have been in accord with the purposes for which, under Florida law, the State owns the area water-ward of high tide (i.e. for "navigation, commerce, fishing, bathing and other easements allowed by law"29 $^{\prime 2}$, the result would be that the former littoral owner is legally no longer a littoral owner and that the State itself owns the newly created littoral property. Under such circumstances any future accretions would inure to it, and it would suffer any future erosion. In such a case, there could be no regulatory taking, as no regulation of the littoral owner's property would be required, and no law would need to set a fixed state/private property boundary.

There is a good deal of authority favoring such a position. I have already mentioned the U.S. Supreme Court decision in the Mission Rock case from California. ${ }^{30}$ Indeed, that was a major issue in the early development of San Francisco. In the mid-nineteenth century, the waterfront was filled and littoral owners were cut off by docks and other structures built on tidelands in front of their properties. ${ }^{31}$ If you visit the city, you may notice that Front Street (whose name once meant what it said) is now about four (filled) city blocks from the waterfront.

In a 1909 Massachusetts case, Home for Aged Women $v$. Commonwealth, ${ }^{32}$ a state river basin commission built a dam and a lock on

29. Adams v. Elliott, 174 So. 731,734 (Fla. 1937).

30. See supra note 12 .

31. See generally Eldridge v. Cowell, 4 Cal. 80 (1854). The predecessor of the plaintiff acquired his waterfront lot in 1847 , and conveyed it to the plaintiff in 1852 . A submerged lot waterward of the plaintiff was conveyed to the defendant in 1848, and in 1851 a law was passed authorizing its filling in to improve waterfront commerce. The plaintiff was cut off from water access and asserted a violation of his riparian rights, and also a nuisance. The Supreme Court of California upheld the filling and the cutting off on the ground that it was legitimate "to destroy the easement, in order to subserve the general good." Id. at 87 . The court added that no riparian right of the plaintiff had been violated since he took in 1852, after the 1851 law was passed and with knowledge of it, but that suggests his predecessor's pre-1851 riparian rights were lost when the tract was sold. This is precisely the sort of claim the U.S. Supreme Court rejected in Palazzolo v. Rhode Island, 533 U.S. 606, 616, 620-21 (2001) (plurality opinion).

32. Home for Aged Women v. Commonwealth, 89 N.E. 124, 129 (Mass. 1909); see also Carpenter v. City of Santa Monica, 147 P.2d 964, 972 (Cal. Dist. Ct. App. 1944) ("[T]ide lands, filled rapidly and not gradually and imperceptibly, belong to the state ... and do not belong to the upland owner."); Bentz v. McDaniel, 872 So. 2d 978, 980 (Fla. Dist. Ct. App. 2004) ("Filling is not a gradual and imperceptible process which would qualify as natural accretion."). 
the Charles River and filled a strip of submerged land in front of the plaintiff's riparian tract, making the filled land a public park. The riparian owner sued on the ground that the newly created park blocked their riparian right of access to the river and sought damages. ${ }^{33}$ The court denied their claim, holding that:

The waters and the land under them beyond the line of private ownership are held by the state, both as the owner of the fee and as the repository of sovereign power, with a perfect right of control in the interest of the public. The right of the Legislature ... . has been treated as paramount to all private rights .... ${ }^{34}$

The Massachusetts court cited the street access analogy, and said that if the public interest requires the discontinuance of the street, the abutting owner's right of access comes to an end. ${ }^{35}$

The court later distinguished that case on the ground that the park there was part of a larger project for the improvement of navigation, and that the Commonwealth holds the land beneath navigable waters for the limited purpose of protecting navigation and fisheries. ${ }^{36}$ While it is true that the earlier case spoke about the project there as part of an "improvement to a navigable highway," ${ }^{37}$ it also spoke much more generally in the same passage, saying that grants of land bounded by tide water are impliedly subject to paramount government uses of the waterfront "for the promotion of commerce and the general welfare." ${ }^{38}$ And it emphasized the Commonwealth's proprietary posture, saying that "there is no change within the boundaries of the [private upland owner's] estates, and the adjacent land and water [below the MHTL] are held in a separate ownership, for a public use, under which it may be appropriated as the interests of the public require. ${ }^{, 39}$

Definition of the scope and purpose of the state's proprietorship is a matter of state law and varies from state to state. In some states, it is rather strictly limited to navigation, fishing, and fowling, but in others it is

33. Home for Aged Women, 89 N.E. at 125.

34. Id.

35. Id. at 126 .

36. Michaelson v. Silver Beach Improvement Ass'n, 173 N.E.2d 273, 277 (Mass. 1961). Notably, the U.S. Supreme Court has conceived the state's ownership of tidelands more broadly, as including commerce. See supra note 12. (1897)).

37. Home for Aged Women, 89 N.E. at 127 (quoting Gibson v. United States, 166 U.S. 269, 275

38. Id.

39. Id. at 129. 
considerably more broadly defined. ${ }^{40}$ As noted earlier, Florida includes bathing and recreation among its public trust uses, ${ }^{41}$ and enhancing public beaches, particularly where loss of beach land through storm-caused erosion is serious, might well be considered a legitimate proprietary use under that State's background principles of property law.

Another possible state proprietary claim could arise if -as the Florida Supreme Court found - the earlier loss of beach was caused by avulsion, and the public/private boundary did not move landward. In such an event, the foreshore between high and low tide (which formerly had been publicly owned and available for public use) would now be located entirely on land owned by the littoral proprietor and the public might not have a legal right of access to it. ${ }^{42}$ In such a case, assuming it could practically be accomplished without also filling the littoral owner's submerged land (perhaps by building a structure around the littoral owner's submerged land ${ }^{43}$ ), a filling project seaward of the public/private property line (on land which is now wholly submerged) to assure the existence of a publiclyowned, publicly-usable foreshore would almost certainly be within even the most traditional state definition of public trust proprietorship.

Finally, there is the question whether the kind of fill in the Florida-type beach nourishment program would even qualify as an accretion that would

40. E.g., Marks v. Whitney, 491 P.2d 374, 380 (Cal. 1971); White v. Hughes, 190 So. 446, 448 (Fla. 1939) (navigation, fishing, and bathing); In re Water Use Permit Applications, 9 P.3d 409, 448 (Haw. 2000); Mesenbrink v. Hosterman, 210 P.3d 516, 518 (Idaho 2009); People ex rel. Scott v. Chi. Park Dist., 360 N.E.2d 773, 780 (Ill. 1976); Glass v. Goeckel, 703 N.W.2d 58, 74 (Mich. 2005); Cinque Bambini P'ship v. State, 491 So. 2d 508, 512 (Miss. 1986); Borough of Neptune City v. Borough of Avon-by-the-Sea, 294 A.2d 47, 52 (N.J. 1972); Orion Corp. v. State, 747 P.2d 1062, 1072-73 (Wash. 1987). See generally David C. Slade et AL., Putting the PUblic Trust to WORK (1997) (stating that traditional public trust uses are navigation, fishing, bathing, hunting, skating, cutting ice, etc.).

41. Adams v. Elliott, 174 So. 731,734 (Fla. 1937).

42. Traditionally, during submergence, the boundary would not move, but there would be a public easement in the water; whether it would include public use of the intertidal zone is unclear. The upland owner could reclaim the land if the water later declined, under a doctrine known as reemergence. But there is no historical authority for the right of the state to fill such land. See generally Joseph L. Sax, The Accretion/Avulsion Puzzle [etc.], TUL. ENVTL. L.J. (forthcoming 2010).

Some states have changed the common law rule by statute; e.g., North Carolina law now provides that the seaward boundary of all property that adjoins the ocean is the mean high water mark. N.C. GEN. STAT. § 7-20(a) (2009). See Joseph J. Kalo, North Carolina Oceanfront Property and Public Waters and Beaches: The Rights of Littoral Owners in the Twenty-First Century, 83 N.C. L. REv. 1427, 1436 (2005).

43. Alternatively, it would be necessary to fill the privately owned area between the preerosion, pre-avulsion MHTL, and the current MHTL. The Florida Supreme Court seemed to think the state could do that without compensating the littoral owner, which seems a novel view of the right of reclamation of avulsively eroded land. In any event, such a situation would present some perplexing issues in order to have a publicly owned foreshore, which is yet another reason to doubt the contemporary value of the avulsion nule. See generally Sax, The Accretion/Avulsion Puzzle, supra note 42. 
belong to the littoral owner. If not, the argument that the sand placed on state land just seaward of the MHTL is an accretion and belongs to the upland owner would be legally erroneous. The issue is whether dumping dredged sand on the land is within the historic scope of the accretion rule under the background accretion property law rule.

The historic common law development, up to and including Blackstone, did not deal with artificial accretions one way or another. Even when artificial accretions were first said to come within the accretion rule in America in the nineteenth century, the cases involved gradual additions of alluvium generated by structures like jetties and groins, and not dredging and dumping of sand, as in some modern beach nourishment cases. ${ }^{44}$ There is at least some reason to think that judges did not think the accretion rule applied to such fill projects. ${ }^{45}$

It is now the law virtually everywhere that an artificial, rather than natural, process does not prevent alluvium from qualifying as accretion, so long as it has not been created by the littoral owner himself. ${ }^{46}$ That is clearly the law in Florida, as was held in a case where a state beach nourishment project was accomplished by construction of a jetty that gradually caused alluvion to build up in front of the defendant's littoral tract. ${ }^{47}$ However, traditional doctrine requires that the process be gradual

44. See e.g., Jones v. Johnston, 59 U.S. (18 How.) 150 (1855) (noting that harbor construction and pier extensions led to gradual additions of alluvium, as earth and sand washed up onto the shore).

45. See Marine Ry. \& Coal Co. v. United States, 257 U.S. 47, 66 (1921); see also Gibson v. United States, 166 U.S. 269, 275-76 (1897); Transp. Co. v. Chicago, 99 U.S. 635, 635-42 (1878) (acknowledging that legitimate public projects on public submerged lands (such as dikes) cutting off a riparian owner's access to the water did not constitute an expropriation of the riparian owner's property, though such cases may have assumed only a narrowly conceived pre-existing servitude in favor of navigation); Home for Aged Women v. Commonwealth, 89 N.E. 124, 129 (Mass. 1909) (no expropriation for project that included fill for parkland); Bruning v. City of New Orleans, 115 So. 733, 738 (La. 1928) (Where the city had filled in submerged land to create a park, the court denied the upland owner's claim of ownership and said: "There is, of course, no such thing as a 'right of batture, alluvions, and accretions' on the shore of Lake Ponchartrain, an arm of the sea ... nor in any case as to lands reclaimed by artificial process and with public money....").

46. See generally Riparian Owner's Right to New Land Created by Reliction or by Accretion Influenced by Artificial Condition Not Produced by Such Owner, 63 A.L.R.3d 249, 255-56 (1975) (outlining case of County of St. Clair v. Lovingston, 90 U.S. 46 (1874) and upholding riparian owner's claim to alluvium collected by accretion). Artificial accretion cases usually involve accretion in the traditional sense, as, for example, where a jetty or dike causes alluvion to drift to shore and build up gradually.

Califomia is an exception. See State ex rel. State Lands Comm'n v. Superior Court, 900 P.2d 648, 666 (Cal. 1995) (recognizing an exception for distant artificial accretions); Carpenter v. City of Santa Monica, 147 P.2d 964, 973 (Cal. Dist. Ct. App. 1944) (stating that, for tidelands, where the state is an adjacent owner, accretions do not belong to the upland owner); see also Bruning v. City of New Orleans, 115 So. 733, 738 (La. 1928) (denying landowner's claim to accreted land).

47. Bd. of Trs. of Internal Improvement Trust Fund v. Sand Key Assocs., 512 So. 2d 934, 937 (Fla. 1987). 
and imperceptible to qualify as an accretion, and it is doubtful that a beach nourishment program effectuated by dredging and then dumping sand would meet those tests. ${ }^{48}$ In Florida, an appellate court has said that "[f]illing is not a gradual and imperceptible process which would qualify as natural accretion." $\$ 9$ Indeed, an older Florida case held that a state lakelowering project, which exposed shore land, was not a reliction (legally the mirror-image of accretion), one reason being that the water did not recede "by imperceptible degrees." And Florida courts recognize the common law rule that "boundaries do not shift when the loss of land occurs suddenly ... rather than gradually." ${ }^{\text {51 }}$ Presumably the same rule would apply to gain of land.

Perhaps the proprietary claims that I have spelled out here would fail in whole or part under Florida's analysis of its background principles of state property law. ${ }^{52}$ My point is simply that in a case like this, the state is at the least entitled to place itself on an equal proprietary plane with the landowner who is challenging it. It may prevail in whole or in part as a proprietor. ${ }^{53}$ If it does, its valid proprietary action cannot constitute a

48. E.g., City of Long Branch v. Liu, 833 A.2d 106 (N.J. Super. Ct. Law Div. 2003) (Federal beach replenishment program held to be avulsion); In re Driveway in New York, 93 N.Y.S. 1107, 110708 (1905) (rejecting the view that filled-in land should be treated as an accretion, saying the accretion rule only applies to gradual and natural deposits of soil at the edge of the upland property); see City of Long Branch v. Liu, 2009 WL 1393221 (N.J. Super. App. Div. 2009) (unpublished opinion) ("We do not find it necessary in order to resolve this issue that we delve into the distinctions drawn by the common law with respect to boundary lines between accretion ... and avulsion .... It is undisputed that the enhanced beachland to which defendants seek to lay claim and for which they seek compensation was the result of a public agency spending public funds. We can perceive no policy justification which would permit defendants to reap such a private monetary benefit from those public efforts."); see also Wildwood Crest v. Masciarella, 240 A.2d 665, 669-70 (N.J. 1968) ("[A]rtificially filled tide lands filled rapidly and not gradually and imperceptibly, belong to the state or its grantees and do not belong to the upland owner."). Carpenter v. City of Santa Monica, 147 P.2d 964, 972 (Cal. Dist. Ct. App. 1944).

49. Bentz v. McDaniel, 872 So. 2d 978, 980 (Fla. Dist. Ct. App. 2004).

50. Martin v. Busch, 112 So. 274, 287 (Fla. 1927).

51. Trepanier v. County of Volusia, 965 So. 2d 276, 283 (Fla. Dist. Ct. App. 2007); Walton County v. Stop the Beach Renourishment, Inc., 998 So. 2d 1102, 1116 (Fla. 2008), cert. granted, 77 U.S.L.W. 3673 (U.S. June 15, 2009) (No. 08-1151) (U.S. argued Dec. 2, 2009). At the Supreme Court level, the party names are now Stop the Beach Renourishment, Inc. v. Florida Department of Environmental Protection. Id.

52. Courts seem quite able to make doctrine fit a desired outcome. See State v. Gill, 66 So. 2d 141, 145 (Ala. 1953) (holding quite justly, if without much legal support, that land created by government dumping of waste mud upland from a dredging project was accreted to the littoral owner of that upland tract).

53. As indicated earlier, I think the property rule should be one of seeking balance. Thus, even though as an owner the state might totally cut off the littoral owner, the more balanced result set out in the Florida statute seems desirable, giving the upland owner access and use, and limiting development on the public beach. Subjecting upland owners to public access along the shore is hardly the end of the world, as anyone who has ever vacationed in Hawaii knows. There, all beaches, even in front of the most luxurious hotels and the richest residents' homes, are publicly accessible up to the vegetation line. 
taking. Of course, it is not obliged to follow that path. It can always opt to defend its actions under the regulatory takings rubric.

And still Hawaiian tourism and real estate prospers. See In re Application of Ashford, 440 P.2d 76, 77 (Haw. 1968) (noting that the seaward boundary between private upland and public beach is "along the upper reaches of the wash of waves, usually evidenced by the edge of vegetation or by the line of debris ...."), aff'd, Diamond v. State, 145 P.3d 704, 712 (Haw. 2006). 